\title{
Statik Manyetik Alanın Trombosit Agregasyonuna Etkisi*
}

\section{The Effect of Static Magnetic Field on Platelet Aggregation}

\author{
Çiğgdem Bayram Gürel ${ }^{1}$ (D), Gülsel Ayaz ${ }^{1}$ (D), Handan Tuncel² (D), Tunaya Kalkan² (D, \\ Nazmiye Kurşun $^{4}$ (D) Turgut Ulutin ${ }^{1}$ (D)
}

\footnotetext{
* Bu çalışma daha önce $15^{\text {th }}$ International Congress of Histochemistry and Cytochemistry (ICHC) "From Molecules to Diseases" 10.5505/2017ichc.PP-70 [Structure and function of the cell] May 18 - 21, 2017. Antalya/Türkiyede poster olarak sunulmuştur.

1 İstanbul Üniversitesi Cerrahpaşa, Cerrahpaşa Tip Fakültesi, Tibbi Biyoloji Anabilim Dalı, İstanbul, Türkiye

2 İstanbul Üniversitesi Cerrahpaşa, Cerrahpaşa Tip Fakültesi, Biyofizik Anabilim Dalı, İstanbul, Türkiye

3 İstanbul Aydın Üniversitesi Tip Fakültesi Biyofizik Anabilim Dalı, İstanbul, Türkiye

${ }^{4}$ Ankara Üniversitesi Tip Fakültesi, Biyoistatistik Anabilim Dal, İstanbul, Türkiye
}

ORCID: Ç.B.G. 0000-0001-9407-7735;

G.A. 0000-0003-3085-232X;

H.T. 0000-0002-1926-9566

M.T.K. 0000-0001-9783-8835;

N.K. 0000-0001-7424-9835;

T.U. 0000-0002-0406-1746

Corresponding author/Sorumlu yazar:

Çiğdem Bayram Güler,

İstanbul Üniversitesi Cerrahpașa, Cerrahpaşa

Tip Fakültesi, Tıbbi Biyoloji Anabilim Dalı,

İstanbul, Türkiye

E-mail: bayram@istanbul.edu.tr;

cigdembayramgurel@gmail.com

Submitted/Başvuru: 18.09.2020

Accepted/Kabul: 12.10 .2020

Citation/Atıf: Bayram Gurel C, Ayaz G, Tuncel H, Kalkan T, Kursun N, Ulutin T. The Effect of Static Magnetic Field on Platelet Aggregation. Sağllk Bilimlerinde İleri Araştırmalar Dergisi 2020; 3(3): 173-178.

https://doi.org/10.26650/JARHS2020-796725
ÖZ

Amaç: Trombositler, salgıladıkları maddeler ve membran proteinleri ile birlikte koagülasyon ve inflamasyonda önemli rol oynayan 4-7 Mikron çapında kan hücreleridir. Manyetik alanın günümüzde, canlılara ve kan hücrelerine etkilerini araştıran birçok çalışma olmakla birlikte henüz etki mekanizması tam olarak açıklanamamıştır. Özellikle düşük sabit manyetik alanın lökositleri aktive ettiği ve sayılarını arttırdığı tespit edilmiștir fakat trombositler üzerindeki etkileri ile ilgili tartışmalı veriler mevcuttur. Bu çalışmada sabit manyetik alanın trombosit fonksiyonları üzerindeki etkilerini incelemeyi amaçladık.

Gereç ve Yöntem: Trombositler farklı şiddetlerdeki $(2 \mathrm{mT}, 5 \mathrm{mT}, 40 \mathrm{mT})$ manyetik alana, farklı sürelerde $(5,15$ ve 30 dakika) maruz birakıldı ve trombosit agregasyonları farkl zaman aralıklarında (0,24, 40, 48 saat) agregometre kullanılarak tespit edildi. ADP uyaranı kullanılarak trombosit agregasyon kurbu eğim ve \% amlitüd olarak belirlendi.

Bulgular: $5 \mathrm{mT}$ 'da $15 \mathrm{dk}$ ve $30 \mathrm{dk}$ inkübasyondan sonra 24 . saatteki trombosit agregasyonları, kontrole göre daha yüksek bulundu (eğim $\mathrm{p}=0,008$, amplitüd $\mathrm{p}=0,026$ ). 15 ve 30 dakika arasında ise istatistiksel olarak anlamlı bir fark saptanmadı. 2 mT'da 15 ve 30 dakika inkübasyondan sonra 48. saatteki agregasyonları kontrole göre anlamlı olarak yüksek bulundu ( $\mathrm{p}=0,038) .2 \mathrm{mT}$ 'daki trombosit agregasyonu, $5 \mathrm{mT}$ 'daki trombosit agregasyonundan istatistiksel olarak daha yüksek bulundu $(\mathrm{p}=0,032)$.

Sonuç: Manyetik alana maruz kalan trombositlerde agregasyon artışı olduğu tespit edildi. $2 \mathrm{mT}$ 'lık statik manyetik alan maruziyetinin 48 saat sonra bile trombosit agregasyon yanıtını olumlu etkilemesi, bu etkinin trombositlerin vücut dışında daha uzun süre aktivitelerini korumalarını sağlayacağını düşündürmektedir.

Anahtar Kelimeler: Statik manyetik alan, trombosit agregasyonu, ADP

\section{ABSTRACT}

Objective: Platelets are 4-7 Micron diameter blood cells that play an important role in coagulation and inflammation with the substances they secrete and the membrane proteins. Although there are many studies investigating the effect of a magnetic field on living organisms and blood cells, it's mechanism has not been clarified yet. It has been demonstrated that the low-intensity magnetic field activates the leukocytes and increases their number, but there are controversial data regarding its effect on platelets. In this study, we aimed to examine the effects of a magnetic field on platelet functions.

Materials and Methods: Platelets were exposed to different intensities of magnetic field $(2 \mathrm{mT}, 5 \mathrm{mT}, 40 \mathrm{mT})$ at different times $(5,15$ and 30 minutes) and the aggregation of platelets was detected at different time intervals $(0,24,40,48$ hours) using the aggregometer.The platelet aggregation curve was determinated as slope and amlitude (\%).

Results: After a $15^{\prime}$ and $30^{\prime}$ incubation at $5 \mathrm{mT}$, platelet aggregation at the 24th hour was found to be higher than the control (Slope $\mathrm{p}=0.008$, Amplitude $\mathrm{p}=0.026$ ). There was no statistical difference between 15 and 30 minutes. The 48th hour aggregation was found to be significantly higher than the control after a $15^{\prime}$ and $30^{\prime}$ incubation at $2 \mathrm{mT}(\mathrm{p}=0.038)$. Platelet aggregation at $2 \mathrm{mT}$ was higher than platelet aggregation at $5 \mathrm{mT}(\mathrm{p}=0.032)$.

Conclusion: It was determined that there was an increase in aggregation of platelets exposed to a magnetic field. The fact that $2 \mathrm{mT}$ static magnetic field exposure positively affects the platelet aggregation even after 48 hours, suggests that this effect will enable the platelets to maintain their activities outside of the body for a longer time.

Key words: Static magnetic field, platelet aggregation, ADP 


\section{GİRIŞ}

Trombositler; çok işlevli, karmaşık, çekirdeksiz hücrelerdir ve salgıladıkları ajanlar ve membran glikoproteinleri sayesinde hemostazda, trombozda ve inflamasyonda rol oynarlar. Vasküler endotel yüzeyinde hasar oluştuğunda, trombositler subendotelyal matrikste bulunan; kolajen, fibronektin, von Willebrand Faktör (vWF), trombospondin-1, lamininler, mikrofibriller ve fibrinojen gibi matriks bileşenlerine bağlanırlar. Bu bağlanmayı trombosit membranında integrin ailesinin üyelerinden olan, glikoprotein (Gp) Ia/IIa ve Gp VI aracılı̆̆ ile gerçekleştirirler. Aktive olan trombositler şekil değiştirerek yapışkan özellikte olan vWF ile daha sağlam bir tıkaç oluştururlar. vWF trombosit yüzey reseptörü olan Gp Ib/IX ile kolajen lifleri arasında bir köprü görevi görür $(1,2)$. Böylece hasar bölgesine trombosit adezyonu olur. Trombosit adezyonundan saniyeler sonra şekil değişikliği gösteren trombositler ince uzun psödopodlar oluştururlar. Trombositler içindeki mikrofibrillerin kasılması sonucunda trombositlerdeki granüller hücre yüzeyine göç eder ve hücre dışına salgılanır. Salgılanan bu maddeler; adenozin difosfat (ADP), trombospodin, vWF, fibronektin, fibrinojen, heparinaz, tromboksan $\mathrm{A}_{2}$ $\left(\mathrm{TXA}_{2}\right)$ ve faktör Vadır. Adezyondan sonra gerçekleşen bu aşama sekresyon aşamasıdır. Sekresyon aşamasında; trombositlerin yüzeyi ile bağlantılı kanaliküler sistem ve tubuler sistem rol oynar. Bu aşamadan sonra ise üçüncü aşama; agregasyon aşamasıdır. ADP ve TXA2; hasar bölgesinde trombosit agregasyonunu uyaran maddelerdir. Trombosit membranındaki GpIIb/ IIIa aktive olarak fibrinojene bağlanır ve trombosit agregasyonu gerçekleşir. Sonuç, hasar yerinde bir trombosit tıkacıdır. Trombositlerin aktivasyonu, yüzeylerindeki fosfolipidlerde değişikliklere yol açar. Bu fosfolipidler ayrıca bazı pıhtılaşma faktörlerini aktive ederek trombosit prokoagülanını da aktive eder. Trombositlerin herhangi bir fonksiyonundaki kusur, birincil hemostatik tıkacın bozulması nedeniyle kanamaya neden olur. Trombosit disfonksiyonu kalitsal veya edinilmiş olabilir. Kalıtsal bozukluklar nadir olmakla birlikte, kazanılmış olanlarla sık karşılaşılır $(3,4,5)$.

İnsan yapımı statik manyetik alanlar (SMA), beynin ve diğer yumuşak dokuların üç boyutlu gö- rüntülerini sağlayan manyetik rezonans görüntüleme (MR) gibi tıbbi uygulamalarda kullanılmaktadır. Taranan hastalar ve makine operatörleri bu nedenle çok yüksek mukavemetli SMA' a maruz kalabilirler. Yüksek mukavemetli SMA' a maruz kaldıktan sonraki biyolojik tepki, son zamanlarda, olası sağlık yararlarının yanı sıra potansiyel yan etkiler açısından da geniş ölçüde tartışılmaktadır. Şu anda, araştırma uygulamalarında daha yüksek çözünürlüklü görüntüleme elde etmek için tüm vücut taramasında 9,4 T’ye kadar güçlü SMA kullanılmaktadır (6). Yüksek mukavemetli SMA'nın neden olduğu biyolojik etkiler araştırılmaktadır ve bu tür maruziyet ile ilgili hala önemli güvenlik sorunları vardır. Hastanın MA’a maruz kalmasına ilişkin yönergeler; ABD Gıda ve İlaç Yönetimi, Uluslararası Elektroteknik Komisyonu, Ulusal Radyolojik Koruma Kurulu ve İyonlaştırıcı Olmayan Radyasyondan Korunma Uluslararası Komisyonu gibi çeşitli dünya örgütleri tarafından verilmektedir (6).

Yüksek mukavemetli SMA’nın yanı sıra düşük SMA’nın da hücreler üzerindeki etkilerini araştıran çalışmalar mevcuttur. Bu çalışmalarda düşük sabit manyetik alanın lökositleri aktive ettiği ve sayılarını arttırdığı gösterilmiştir. Ancak düşük SMA'nın trombositlere etkisinin hangi yönde olduğu ile ilgili veriler tartışmalıdır $(7,8)$. Biz bu çalışmada sabit manyetik alanın trombosit fonksiyonları üzerindeki etkilerini incelemeyi amaçladık.

\section{GEREÇ VE YÖNTEM}

Gönüllü sağlıklı kişilerden 09:00-11:00 saatleri arasında kan örnekleri alındı. \%3,2'lik sitratlı vakumlu tüplere alınan kanlar önce 300G'de oda s1caklığında 20dk santrifüj edildi. Tüpün en üst kısminda kalan trombositten zengin plazma (TZP) toplanarak plastik bir tüpün içerisine aktarıldı. Elde edilen TZP farklı şiddetlerde (40mT, $5 \mathrm{mT}, 2 \mathrm{mT})$ statik manyetik alana, farklı sürelerde $(5 \mathrm{dk}, 15 \mathrm{dk}$ ve $30 \mathrm{dk})$ maruz birakıldı. Manyetik alan maruziyetinden sonra farklı zaman aralıklarında (0. saat, 24. saat, 40 . saat ve 48 . saat) trombosit agregasyonlar1 ölçüldü. Trombosit agregasyon testi agregometre cihazı (Chrono-Log 500-CA, 500CA Whole Blood 
Lumi Aggregometer, CHRONO-LOG CORP., Havertown, PA, USA) ile gerçekleştirildi. Bunun için; $500 \mu \mathrm{L}$ TZP agregometre cihazında $37 \mathrm{C}^{\circ}$ 'de $3 \mathrm{dk}$ inkübe edildi. İnkübasyon sonrasında trombosit agregasyonunun tetiklenmesi için TZP içine son konsantrasyon $1 \mu \mathrm{M}$ olacak şekilde ADP (CHRONO-LOG CORP., Havertown, PA, USA) eklendi. 3dk boyunca agregasyon kurbunun oluşması beklendi ve trombositlerin agregasyon hızları ölçüldü. Oluşan agregasyon kurbu eğim (ohm $\Omega$ ) ve \% amlitüd olarak hesaplandı $(9,10,11)$.

İstatistiksel analiz: Verilerin istatistiksel değerlendirmesi SPSS 11.0 kullanılarak yapıldı. Gruplar arası kıyaslamalar için Friedman Testi kullanıldı ve istatistiksel anlamlılık düzeyi $\mathrm{p}<0,05$ olarak kabul edildi.

\section{BULGULAR}

Farklı sürelerde ve farklı şiddetlerde statik sabit manyetik alana maruz kalan trombositler şöyle yanıt vermiştir: $5 \mathrm{mT}$ manyetik alana $15 \mathrm{dk}$ ve $30 \mathrm{dk}$ maruziyetten sonra, 24. saatteki agregasyon, kontrole göre istatistiksel olarak daha yüksek bulundu (Aplitüd $\mathrm{p}=0,026$, Eğim $\mathrm{p}=0,008$, Tablo 1 ). $15 \mathrm{dk}$ ve $30 \mathrm{dk}$ inkübasyon arasında ise istatistiksel olarak anlamlı bir fark bulunmadi. $2 \mathrm{mT}$ manyetik alana $15 \mathrm{dk}$ ve $30 \mathrm{dk}$ maruziyetten sonra 48. saatte ölçülen trombosit agregasyonu kontrole göre istatistiksel olarak daha yüksek bulundu ( $\mathrm{p}=0,038$, Tablo 2). $15 \mathrm{dk}$ ve $30 \mathrm{dk}$ inkübasyon arasında ise istatistiksel olarak anlamlı bir fark tespit edilmedi. 30 dakika süre ile $2 \mathrm{mT}$ ve $5 \mathrm{mT}$ manyetik alana maruz kalan trombositlerin 48 . saatte yapılan agregasyon ölçümleri karşılaştırıldığında, $2 \mathrm{mT}$ 'deki agregasyonun $5 \mathrm{mT}$ 'dekinden istatistiksel olarak daha yüksek olduğu saptandı $(p<0,05$, Tablo 3). 40mT’ya maruz bırakılmış trombositlerin agregasyonunda herhangi bir değişiklik tespit edilmedi ( $p>0,05$, Tablo 3).

\section{TARTIŞMA}

Trombosit agregasyon testi, trombosit fonksiyonlarını tespit edebilmek açısından altın standart olarak kritik bir yere sahiptir $(9,11)$. Diğer kan hücreleri gibi trombositler de diş etkenlerden, oksidan ve iyonojen ajanlardan( manyetik alan) etkilenirler. Teknolojinin günlük hayatımıza fazlaca girmesi ile manyetik alanların hücrelere olan etkisi gittikçe artmıştır. Tıp ve biyoloji alanında manyetik alanın etkilerinin neler olduğu konusunda yapılmış birçok çalışma olmakla birlikte kan hücreleri üzerine nasıl etki ettiği henüz tam olarak açıklanamamıştır. Sağdilek E. ve arkadaşlarının yaptığ 1 bir çalışmada $1 \mathrm{mT}$ ve $5 \mathrm{mT}$ SMA'da 1 saat maruziyet sonrasında trombosit agregasyonunun etkilenmediği bildirilmiştir (12). Bir başka çalışmada ise $6 \mathrm{mT}$ statik manyetik alana maruz birakılan hücrelerin manyetik alandan etkilendiği gösterilmiştir. Özellikle, statik manyetik alanın hem apopitozu hem de mitozu etkilediği belirtil-

Tablo 1. 5mT şiddetinde sabit manyetik alana maruz kalan trombositlerin agregasyon değişimleri

\begin{tabular}{|c|c|c|c|c|c|c|c|}
\hline $5 \mathrm{mT}$ şiddette & & trol & 15 dakik & naruziyet & 30 dakik & naruziyet & \\
\hline $\begin{array}{l}24 \text { saat sonra } \\
\text { trombosit agre- } \\
\text { gasyon ölçümü }\end{array}$ & Ort \pm SS & $\begin{array}{c}\text { Medyan } \\
\text { (Min-maks) }\end{array}$ & Ort \pm SS & $\begin{array}{c}\text { Medyan } \\
\text { (Min-maks) }\end{array}$ & Ort \pm SS & $\begin{array}{c}\text { Medyan } \\
\text { (Min-maks) }\end{array}$ & $\mathbf{p}^{*}$ \\
\hline$\%$ Amplitüd $(\mathrm{n}=7)$ & $7,28 \pm 7,20$ & $9(0-16)$ & $14,71 \pm 11,37$ & $14(0-32)$ & $16,57 \pm 9,47$ & $14(6-35)$ & 0,026 \\
\hline$\Omega$ Eğim $(n=7)$ & $13,0 \pm 1,2.5$ & $19(0-28)$ & $26,14 \pm 18,14$ & $25(0-50)$ & $28,29 \pm 9,46$ & $30(10-39)$ & 0,008 \\
\hline
\end{tabular}

Ort; Ortalama, SS: Standart Sapma, Min; Minimum, Maks; Maksimum, ${ }^{\star}$ Friedman Testi

Tablo 2. $2 \mathrm{mT}$ şiddetinde sabit manyetik alana maruz kalan trombositlerin agregasyon değişimleri

\begin{tabular}{|c|c|c|c|c|c|c|c|}
\hline \multirow{2}{*}{$\begin{array}{l}2 \mathrm{mT} \text { şiddette } \\
48 \text { saat sonra trom- } \\
\text { bosit agregasyon } \\
\text { ölçümü }\end{array}$} & \multicolumn{2}{|c|}{ Kontrol } & \multicolumn{2}{|c|}{15 dakika maruziyet } & \multicolumn{2}{|c|}{30 dakika maruziyet } & \multirow[b]{2}{*}{$\mathbf{p}^{*}$} \\
\hline & Ort \pm SS & $\begin{array}{c}\text { Medyan } \\
\text { (Min-maks) }\end{array}$ & Ort $\pm S S$ & $\begin{array}{c}\text { Medyan } \\
\text { (Min- maks) }\end{array}$ & Ort \pm SS & $\begin{array}{c}\text { Medyan } \\
\text { (Min- maks) }\end{array}$ & \\
\hline$\%$ Amplitüd (n=5) & $5,6 \pm 7,67$ & $0(0-14)$ & $9,8 \pm 12,26$ & $9(0-30)$ & $13,20 \pm 11,28$ & $15(0-29)$ & 0,127 \\
\hline$\Omega$ Eğim $(n=5)$ & $9,0 \pm 12,57$ & $0(0-26)$ & $16,20 \pm 21,28$ & $14(0-52)$ & $25,20 \pm 19,68$ & $27(0-53)$ & 0,038 \\
\hline
\end{tabular}

Ort; Ortalama, SS: Standart Sapma, Min; Minimum, Maks; Maksimum, ${ }^{*}$ Friedman Testi 
Tablo 3. $2 \mathrm{mT}$, $5 \mathrm{mT}$ ve $40 \mathrm{mT}$ sabit manyetik alana 30 dakika süre ile maruz kalan trombositlerin 48 saat sonrasında ölçülen agregasyon değişimleri

\begin{tabular}{|l|c|c|}
\hline \multirow{2}{*}{$\begin{array}{l}\text { İnkübasyon } \\
\text { durumu }\end{array}$} & \multicolumn{2}{|c|}{$\begin{array}{c}\text { 48 saat sonra trombosit agregasyon } \\
\text { ölçümü }\end{array}$} \\
\cline { 2 - 3 } & $\begin{array}{c}\text { \% Amplitüd } \\
(\mathbf{n}=\mathbf{5}) \\
\text { Ort } \pm \text { SS }\end{array}$ & $\begin{array}{c}\mathbf{\Omega} \text { Eğim } \\
(\mathbf{n}=\mathbf{5}) \\
\text { Ort } \pm \text { SS }\end{array}$ \\
\hline Kontrol & $5,60 \pm 7,67$ & $9,0 \pm 12,57$ \\
\hline $2 \mathrm{mT}$ & $13,20 \pm 11,28^{*}$ & $25,2 \pm 19,68$ \\
\hline $5 \mathrm{mT}$ & $2,80 \pm 6,26^{*}$ & $5,6 \pm 12,52$ \\
\hline $40 \mathrm{mT}$ & $12,6 \pm 12,99$ & $21,6 \pm 21,68$ \\
\hline
\end{tabular}

Ort; Ortalama, SS:Standart Sapma, ${ }^{*}$ Friedman Testi $\mathrm{p}<0,05$

miştir. Apoptozun artışının veya azalışının hücre tipine ve SMA'nın maruziyet süresine bağlı olduğu belirtilen çalışmada bu etkinin hücre içi $\mathrm{Ca}^{+2}$ iyon konsantrasyonu üzerinden olabileceği vurgulanmıştır. Hücre içerisinde $\mathrm{Ca}^{+2}$ iyon konsantrasyonunun artmasının hücre sinyal mekanizmalarını etkileyerek apopitozu tetikleyen mekanizmalar arasında yer aldığ 1 belirtilmiştir (13). Plazma membranı; biyoelektrik özellikleri nedeniyle, hücre içi ve hücre dışı farklı iyon konsantrasyonlarına sahiptir. Bu özellik hücrenin polarizasyon ve depolarizasyon mekanizmasının temelini oluşturur. Plazma membranının sahip olduğu biyoelektrik yük, manyetik alanın etkisini gösterdiği ilk yerdir. Bu nedenle, plazma membranının yapısal ve biyofiziksel değişiklikleri, reseptör bağlanmasını veya aktivasyonunu etkileyerek genel olarak hücre fonksiyonunu etkileyecektir. Özellikle, statik manyetik alanların çeşitli deneysel modellerde organizmanın hücre içine $\mathrm{Ca}^{+2}$ salınımını değiştirdiği öne sürülmüştür. Ancak bu etkinin hücre tiplerine göre artış ya da azalış olarak farklılık gösterdiği de belirtilerek hücrenin manyetik alana olan cevabının sadece bu mekanizma ile açıklanamayacağı bildirilmiştir $(13,14,15,16)$.

Çalışmamızı trombositlerin aktivitesini belirleyen testlerden biri olan, membran glikoproteinleri üzerinden gerçekleşen agregasyon testi ile gerçekleştirdik. Trombosit agregasyonu üzerine en etkili manyetik alan şiddetinin $2 \mathrm{mT}$ olduğunu tespit ettik. Bu etki 5mT'da da istatistiksel olarak anlamlı fark yaratmasına rağmen $2 \mathrm{mT}$ kadar güçlü değildi. $2 \mathrm{mT}$ 'nın trombosit agregasyonuna etkisi sadece 15 ve 30 dakikalık kısa süreli maruziyette bile ortaya çıkabiliyordu.

\section{SONUÇ}

Çalışmamızda elde ettiğimiz bir başka sonuç ise $2 \mathrm{mT}$ ve $5 \mathrm{mT}$ 'ya $15 \mathrm{dk}$ ve $30 \mathrm{dk}$ boyunca maruz kalan trombositlerin 24 ve 48 saat sonra bile, manyetik alana maruz kalmayan (yani kontrol) trombositlerden daha aktif olduklarıydı. Bu gözlem bize trombositlerin vücut dışına alındıktan sonra $2 \mathrm{mT}$ statik manyetik alana maruz bırakılarak daha uzun süre canlı kalabilecekleri fikrini verdi. Bir sonraki çalışmamızda bu verinin kuvvetlenmesi için örnek sayısını arttırmayı ve hücre içi ve hücre dışı $\mathrm{Ca}^{+2}$ iyon konsantrasyonlarını tespit ederek verileri analiz etmeyi planlamaktayız.

Düşük dozlu statik manyetik alan çalışmalarının yanı sıra yüksek dozlu statik manyetik alan çalışmaları da yapılmaktadır. Görüntüleme teknolojileri arasında yüksek dozlu manyetik alanların teşhis amaçlı kullanımı gittikçe artmaktadır. Yüksek dozda manyetik alanın hücrelerin farklılaşma veya proliferasyonuna da neden olduğunu gösteren çalıșmalar mevcuttur. Yapılan bir çalışmada CD34 hücreleri, 4 ile 16 saat boyunca en güçlü manyetik alan gradyanına (41,7 T/dakika) sahip 5 T SMA’a veya manyetik alan gradyanı içermeyen 10T SMA’a maruz birakılmıştır. Toplanan hücrelerde, 16 saat süreyle 10T SMA’a maruz birakıldıktan sonra, toplam artış oluşturan birim eritroid ve megakaryosit progenitör hücrelerden üretilmiş koloni oluşumunda hematopoetik öncüllerde önemli bir artış gözlenmiş, böylece kontrolden 1,72 ve 1,77 kat daha fazla çoğaldıkları tespit edilmiştir. Ayrıca, erken hematopoez ve hücre döngüsü ile ilgili genlerin, SMA’a maruz kalma ile önemli ölçüde arttığı bulunmuştur. Bu sonuçlar, 10T SMA maruziyetinin gen ekspresyonlarını değiştirebileceğini ve pluripotent hematopoietik kök hücrelerden megakaryositik/ eritroid progenitör (MEP) farklılaşmasında ve/veya bipotent MEP proliferasyonunda spesifik bir artışa neden olabileceğini göstermektedir (6).

Sonuçta $2 \mathrm{mT}$ ve $5 \mathrm{mT}$ şiddetinde statik manyetik alan trombosit fonksiyonlarının vücut dışına çıktık$\tan 48$ saat sonra bile devam etmesini sağlayabiliyor. 
SMA trombosit agregasyonunu arttırarak etkisini gösteriyor. Ancak mekanizmanın aydınlatılması için daha çok çalışmaya ihtiyaç vardır. $2 \mathrm{mT}$ ve $5 \mathrm{mT}$ şiddetindeki SMA maruziyetinin trombositlerin (kan alındıktan sonra) daha verimli daha uzun süre kullanılmasına yardımcı olabileceği kanaatindeyiz.

Etik Komite Onayı: Bu çalışma için etik komite onayı İstanbul Üniversitesi Cerrahpaşa Tip Fakültesi Etik Kurulu'ndan alınmıștır. (tarih 17/10/2006 ve no 26527).

Ethics Committee Approval: This study was approved by the Ethical Committee of the Istanbul University Cerrahpasa Faculty of Medicine. (date 17/10/2006 ve no 26527).

Bilgilendirilmiş Onam: Katılımcılardan bilgilendirilmiş onam alınmıştır.

Informed Consent: Written consent was obtained from the participants.

Hakem Değerlendirmesi: Dış bağımsız.

Peer Review: Externally peer-reviewed.

Yazar Katkıları: Çalışma Konsepti/Tasarım Ç.B.G., T.K.; Veri Toplama- G.A., Ç.B.G.; Veri Analizi/Yorumlama- Ç.B.G., H.T., T.K., N.K., T.U.; Yazı TaslağıÇ.B.G., G.A., N.K.; İçeriğin Eleştirel İncelemesi- T.U., Ç.B.G., H.T., T.K.; Son Onay ve Sorumluluk- Ç.B.G., H.T., G.A., T.K., N.K., T.U.; Malzeme ve Teknik Destek- Ç.G.B., T.K.; Süpervizyon- H.T., T.U., T.K.

Author Contributions: Conception/Design of Study- Ç.B.G., T.K.; Data Acquisition- E G.A., Ç.B.G.; Data Analysis/Interpretation- Ç.B.G., H.T., T.K., N.K., T.U.; Drafting Manuscript- Ç.B.G., G.A., N.K.; Critical Revision of Manuscript- T.U., Ç.B.G., H.T., T.K.; Final Approval and Accountability- Ç.B.G., H.T., G.A., T.K., N.K., T.U.; Technical or Material SupportÇ.G.B., T.K.; Supervision- H.T., T.U., T.K.

Çıkar Çatışması: Yazarlar çıkar çatışması beyan etmemişlerdir

Conflict of Interest: Authors declared no conflict of interest.

Finansal Destek: Yazarlar finansal destek beyan etmemişlerdir.

Financial Disclosure: Authors declared no financial support.

\section{KAYNAKLAR/REFERENCES}

1. Borges I, Sena I, Azevedo P, Andreotti J, Almeida V, Paiva A, et al. Lung as a Niche for Hematopoietic Progenitors. Stem Cell Rev Rep 2017;13(5):567-74.

2. Lefrancais E, Looney MR. Platelet Biogenesis in the Lung Circulation. Physiology (Bethesda) 2019;34(6):392-401.

3. Choi JL, Li S, Han JY. Platelet function tests: a review of progresses in clinical application. Biomed Res Int 2014;456569.

4. Yardimci TU, Ulutin ON. Glucose-6-phosphate dehydrogenase activity in human platelets and its secretion. New Istanbul Contrib Clin Sci 1976;11(3):142-7.

5. Ulutin ON, Akman N, Ozcan E. [THROMBOSIS, ARTERIOSCLEROSIS AND HYPERCOAGULABILITY] [Article in Turkish] Turk Tip Cemiy Mecm 1963;29:428-32.

6. Monzen S, Takahashi K, Toki T, Ito E, Sakurai T, Miyakoshi J, et al. Exposure to a MRI-Type High-Strength Static Magnetic Field Stimulates Megakaryocytic/Erythroid Hematopoiesis in CD34+ Cells From Human Placental and Umbilical Cord Blood. Bioelectromagnetics 2009;30:280-5.

7. Tenuzzo B, Vergallo C, Dini L. Effect of $6 \mathrm{mT}$ static magnetic field on the bcl-2, bax, p53 and hsp70 expression in freshly isolated and in vitro aged human lymphocytes. Tissue Cell 2009;41(3):169-79.

8. Dini L, Abbro L. Bioeffects of moderate-intensity static magnetic fields on cell cultures. Micron 2005;36(3):195-217.

9. Tutluoglu B, Gurel CB, Ozdas SB, Musellim B, Erturan S, Anakkaya AN. et al. Platelet function and fibrinolytic activity in patients with bronchial asthma. Clin Appl Thromb Hemost 2005;11:77-81.

10. Melanie M, White BA. Platelet protocol research and clinical laboratory procedures printed in the United States of America. Academic Press March 12, 1999.

11. Gungor ZB, Sipahioglu N, Sonmez H, Ekmekci H, Toprak S, Ayaz G, et al. Endothelial 
Dysfunction Markers in Low Cardiovascular Risk Individuals: Comparison of Males and Females J Med Biochem 2017; 36(1): 62-72.

12. Sağdilek E, Sebik O, Çelebi G. $1 \mathrm{mT}$ ve $5 \mathrm{mT}$ statik manyetik alanların trombosit agregasyonuna etkisi. Ege Tip Dergisi 2009; 48 (2), 71-6.

13. Tenuzzo B , Chionna A, Panzarini E, Lanubile R, Tarantino P, Di Jeso B, et al. Biological effects of $6 \mathrm{mT}$ static magnetic fields: a comparative study in different cell types. Bioelectromagnetics 2006;27(7):560-77.
14. Luciana D, Luigi A. Bioeffects of moderateintensity static magnetic fields on cell cultures. Micron 2005;36(3):195-217.

15. Miyakoshi J. Effects of static magnetic fields at the cellular level. Prog Biophys Mol Biol 2005;87(2-3):213-23.

16. Teodori L, Göhde W, Maria GV, Fausto T, Dario C, Barbara P, et al. Static magnetic fields affect calcium fluxes and inhibit stressinduced apoptosis in human glioblastoma cells. Cytometry 2002;49(4):143-9. 